\title{
The Jñanakarmasamuccayavāda in the Commentaries on the Manusmrti
}

\author{
Yoshimizu Kiyotaka
}

According to the jūānakarmasamuccayavāda adopted by some Vedānta scholars, the liberation from transmigration requires the combination (samuccaya) of cognition (jĩana) and action (karman), that is to say, one needs not only to gain insight into the sameness of one's self with the brahman but also carry out one's duties such as Vedic sacrifices residing in a secular society. Among the authors of the commentary on the Manusmrti (Mn), too, Bhāruci (ca. 8th c.) and Medhātithi (9th c.) frequently advocate this position when commenting on the life of the renouncer (parivrājaka) in the sixth chapter of the Mn. ${ }^{1)}$ This paper elucidates on what kinds of action they regard as necessary for the pursuit of liberation and how they contribute to that pursuit.

\section{Ritual's Contribution to Liberation}

The sixth chapter of the Mn, from v. 33 onward, lays out the life of the renouncer. Praising the right insight (samyagdarśana) to be gained through meditation, v. 74 proclaims that one who has gained this insight will not be fettered by actions. Then v. 75 enumerates the four kinds of means to be adopted in everyday life for attaining that state, namely, nonviolence, sensual restriction, Vedic activities, and fierce austerities. Medhātithi explains that Manu advocates the attainment of liberation by means of the combination of $j \tilde{n} \bar{a} n a$ and karman, distributing jūāna to v. 74 and karman to v. 75 (MnBh 522,8-9).

In his commentary on v. 75 , Medhātithi explains how to prove that a sacrifice contributes to the attainment of liberation. He presents the position of an opponent who insists that liberation cannot be a result of a sacrifice, inasmuch as the latter is supposed to bring about a particular result, such as heaven; he then answers this opponent by offering three explanations (MnBh 522,15-18). First, he quotes "he gains it by means of a sacrifice" (yajñena tad āpnoti), a slightly modified part of Śatapathabrāhmaṇa (ŚB) $10.2 .6 .13,{ }^{2)}$ as a Vedic testimony (śruti) promising that a sacrifice can bring about whatever one wishes. 
Second, he maintains that a Mīmāmsā theorem called samyogaprthaktvanyāya is applicable to this case. Applying this theorem, ${ }^{3)}$ one can construe a text to corroborate that the same ritual brings about two different effects. Third, he states that one can distinguish heaven and liberation as two results of the same sacrifice by taking the difference of performance (prayogabheda) into consideration. This means that, if a sacrificer, obsessed by the distinction between himself and others, cannot quit his desire for possession, then a periodical sacrifice brings about an intended but limited result (abhisamhitaparimitaphala), such as heaven, to him; but if, equally considering himself and others, he performs a sacrifice intending only to accomplish his duty (kartavyam iti buddhyā), then it leads him to the brahman, that is, the unlimited supreme bliss (aparimitaniratiśayānanda). According to some (kecit), moreover, Vedic injunctions prompt one to perform a sacrifice by appealing to personal interest, but in reality, they do so merely in the capacity of an expedient in order to lead people who are deeply stained with the consciousness of distinction (bhedagrāha) to the main purpose of human being (pradhāna-purușārtha), that is, liberation. It is just like making an underdeveloped child drink a medicine by saying, "If you drink this, the tuft of your hair will grow" (MnBh 523,7-9).

\section{Vedasaṃnyāsika}

At the end of the sixth chapter, from the last half of v. 86 onward, the Mn lays out and praises the way of life of the person called vedasamnyāsika. Both Bhāruci and Medhātithi derive this term from the compound, vedasamnyāsa, which is analyzed into "vedasya samnyāsah." Both stress, however, that it does not mean to abandon (sam-ni-as) the religion of the Veda. Bhāruci explains the meaning of vedasamnyāsika in two ways. First, it means a retired person who abandoned the means of livelihood (vrttikarman) determined in the Veda after having completed the duties of householder ( $\mathrm{MnV} 45,34-37$ ). Second, in its narrower sense, it means a person who, after showing some indication of his approaching death, has made the ceremony called "total transmission" (sampratti), ${ }^{4)}$ that is, entrusting his son with his entire achievement made in his life (MnV 45,38-39). Bhāruci allows the latter vedasamnyāsika to be occupied with the meditation on the supreme self (paramātman) but stresses that he should not abandon the Vedic sacrifices of simpler forms, such as Agnihotra (MnV 46,2-6). Medhātithi, too, thinks of a retired person as vedasamnyāsika by restricting the religious activities a vedasamnyāsika should abandon to those that need 
money and energy, such as pilgrimage and fasting, and maintains that he should continue to perform morning and evening litanies (samdhyājapa) and the daily Agnihotra until he breathes his last, because he can carry them out by himself with little in the way of expenditure (MnBh 528,4-6; 532,9-10). Even those who are enfeebled by the approach of death should continue the modest rituals laid down in the Veda in order to attain liberation.

\section{Repayment of One's Inborn Debts ( $r n a)$}

After bringing up the vedasamnyāsika as a new topic, the Mn makes an excursion: vv. 87-88 enumerates four áśramas in the sense of the four life-stages, and vv. 89-90 states that the householder is superior to those of the other three aśramas because he supports their livelihoods. Commenting on v. 90, Medhātithi explains how one is obliged to set up a household in one's lifetime. First, if a man merely wishes to put housework into his wife's hands, then he may cohabit with any woman he likes without holding a legitimate wedding $(\mathrm{MnBh} 529,13)$. As regards a person who has overcome his sexual desire during his student life, such a person is not tempted to marry a woman at all (MnBh 529,25). Moreover, some amount of money is indispensable for carrying on living, but it is not impossible to live without a woman (MnBh 529,27-28). Medhātithi concludes that one does not become a householder by marrying a woman in order to gain a visible purpose for one's own pleasure and subsistence, but in order to accomplish one's duty, dharma, which is given preference over individual interests (MnBh 529,28-29).

What, then, is the dharma a householder is entitled to, and how is he proved to be related to that dharma? Each injunction (vidhi) of Vedic sacrifices merely enjoins one to perform a ritual action, and there is no injunction that would induce one to set up the three ritual fires for Vedic sacrifices without aiming at wish fulfillment (MnBh 530,5-6). Instead of seeking ritual injunctions, Medhātithi quotes "jāyamāno brāhmanas tribhir ŗnavām jāyate," a part of Taittirīyasamhitā (TS) 6.3.10.5, ${ }^{5)}$ which states that every Brahmin is born to be in debt $(r n a)$ to $r s i s$, gods and ancestors, and has to discharge these three inborn debts to them, respectively, by studying the Vedas, performing sacrifices and bringing up children. According to Medhātithi, people of ancient times (pūrve) used to consider this Vedic order for the repayment of the tripartite debts ( rnatrayāpākaranaśruti) to oblige each Brahmin to become a householder (MnBh 530,12-13). The birth of a Brahmin mentioned in this statement is his physical birth and not his second birth, that is, the spiritual birth given to 
him by his teacher as a result of initiation (upanayana). Exactly speaking, a Brahmin child incurs these debts when he comes to be conscious of his being entitled to initiation ( $y \bar{a} v a t \bar{a}$ kālenādhikārāvagamo bhavati) (MnBh 530,13-15). Before deciding his career by himself, he has been bred by his family members to begin studies. Thus, he cannot be exempted from the repayment of these debts, and must become a householder right after graduation.

Accordingly, allowing one's own liberation to be pursued only in old age, Medhātithi maintains that the action to be performed as a prerequisite for liberation, in fact, consists of exerting oneself for the maintenance of the community one belongs to, namely, inheriting the Aryan tradition by Vedic studies, strengthening the bond of the contemporary society through sacrifices, and securing the future of one's family through children. Only those who have long been taking care of the past, the present and the future of their communities are entitled to be concentrated on their own liberation at the final stage of life. Medhātithi admits that continuing the duties of a householder until one's old age is exhausting and illustrates the hard life of a householder using a simile of a servant who has become discontented with his life and wishes to put an end to his service because of the oppressive attitude of his master (MnBh 521,17-19). In this simile, the servant bravely makes up his mind to continue to work (karmakarana) until he fully repays his master for the amount of money he received from him in advance (yan mayāsmāt kimcid bhrtyādi grhìtam). Becoming a renouncer before accomplishing the duties of a householder is similar to the desertion of a servant before he pays back his debt, and a renouncer cannot thereby set himself free from the bondage of transmigration.

\section{Adaptation of the "Transfer of the Results of Good and Bad Deeds"}

In his article "The Warrior Taking to Flight in Fear: Some Remarks on Manu 7.94 and 95," 6) Prof. Albrecht Wezler identified a very interesting difference in the interpretations among the authors of the commentary on Mn 6.79. Based on the idea of the so-called "transfer of merits," Mn 6.79 indicates that the renouncer who has become proficient in meditation will be united with the brahman after transferring (visrjya) his good deeds (sukrta) to his favorite people (priyeșu) and his bad deeds (duskgta) to his least favorite people (apriyeșu). ${ }^{7)}$ Medhātithi, however, explains this verse in a very different manner:

One should avoid the mental agitation caused by favor or torment and characterized as pleasure or 
sorrow by the following means: "If someone did something favorable (priya) to me, it is 'viśisyate' to my good deeds. This is the result of that (i.e., my good deeds). He does not do me a favor with kindness. Moreover, [if someone did something least favorable (apriya) to me,] he must have no hostility toward me, and it is my bad deeds that caused [my] suffering." Reflecting in this way, he should bring [the law of retribution] to mind by practicing meditation. In this way, he does not feel affection to one who makes something favorable, nor hatred against one who makes something least favorable (MnBh 524,20-23). ${ }^{8}$

Medhātithi considers this verse to say that a renouncer should attribute the cause of whatever good or bad treatments rendered to him to his own karman, namely, good or bad deeds performed in the past. As Wezler (op. cit., 406-409) points out, Kullūka criticizes Medhātithi and Govindarāja ${ }^{9)}$ by name for modifying the words of Manu and distorting their meaning, poses a question of how the result of good and bad deeds of one person can be transferred to someone else, answering that this transference is corroborated by scriptures and quoting two phrases as examples of Vedic testimony (śruti). Furthermore, Wezler (op. cit., 411-413) elucidates that in his commentary on Brahmasütra (BS) 3.3.26, Śnikara exactly quotes these two phrases and says each of them is transmitted, respectively, in the Śātyāyanins and Kauśitakins, ${ }^{10)}$ and Kullūka notices that BS 3.3.26 refers to these two śrutis. According to Śankara, BS 3.3.26 proves that as regards the śrutis that explicitly state only that an advanced renouncer gets rid of receiving the result of his past good and bad deeds, they imply that the results of these are necessarily transferred to someone else. Accordingly, Wezler observes that, concerning the consequence of karman there is a confrontation between, on the one side, Medhātithi and Govindarāja, who advocate rigid retribution to oneself, and on the other side, Kullūka and Śankara, who hold that the result of a karman necessarily occurs to someone else if the agent of that karman has transcended the law of retribution as a result of his attainment of a highly advanced stage.

Medhātithi is firmly convinced of rigid self-retribution. Mn 6.80-81 enjoins a renouncer to eliminate his attachment (sprha $)$ to everything in order to leave the dualistic outlook (dvandva) caused by attachment, and Mn 6.82 declares that one should meditate upon this instruction. As for how to practice this meditation, Medhātithi provides an illustration of a person who carelessly touches fire and burns his hand, explaining that this person might attribute the cause of his burn to his own carelessness without taking his anger out on the fire. Moreover, Medhātithi recommends that the reader imagine that if a king pleases him by donating a village, then it is due to his own past diligence, and if the king frightens him 
by threatening punishment, then it is due to his own past misdeeds. The real cause of receiving pleasure and pain should not be attributed to others, but to oneself.

With respect to the interpretation of $\mathrm{Mn} 6.79$, it is to be noted that Medhātithi is strongly influenced by Bhāruci, who comments on this verse as follows:

When he experienced "anything favorable" that does not contradict his duties, such as gains of sweet alms and the like, he should [ascribe] its cause [only] to his own [good deeds], namely, assign (viniyujya) his own religious merits (dharma) as its cause, and ignore the person who has brought that to him; likewise, when [he experienced] "anything least favorable," he should ascribe [its cause only to his own] bad deeds by practicing meditation; then he "reaches" the highest "brahman." (MnV 44,1-4). 11)

In this explanation, Bhāruci replaces the verb "vi-srj" given in the pāda c of Mn 6.79 with " $v i-n i-y u j$ " and thereby changes the meaning of " $v i-s r j$ " from "transferring a result to someone else" to "ascribing one's experience to something." 12) Thus, the visisyate given in Ganganath Jha's edition of the MnBh and suspected by Wezler (op. cit., 410, n.52) should be corrected to *visrjyate, which is the passive form of the gerund "visfjya" given in the pāda c of Mn 6.79. Then the phrase "tan mama sukrtasya * visrjyate" comes to mean "it is ascribed to my own good deeds."

Among the authors of the commentary on the BS, Bhāskara, a jñ̄anakarmasamuccayavādin, ${ }^{13)}$ quotes the two śruti passages exactly as Śankara did and gives a similar commentary on BS 3.3.26, answering the same question as posed by Śankara. Moreover, commenting on BS 3.3.28, which states that the person who has departed for the brahman can transfer his own past karman to others as he likes (chandatas), Bhāruci quotes the following half verse from the Rgveda: ${ }^{14)}$

Thus, gods, save us fully today from the sin we committed as well as from [the sin] we did not commit, for the sake of well-being. (RQV 10.63.8cd: té nah krtád ákrtād énasas pár $r_{i} y$ adyá devāsah piprtā $s_{u}$ vastáye //)

This is a prayer to the gods through which man prays, on the one hand, to escape being accused of any sin he actually committed and, on the other hand, to escape being wrongly accused of any sin committed by others, ${ }^{15)}$ presupposing that in the nomadic society of ancient times the struggle for existence is so severe that securing one's survival is more important than achieving social justice and that man does not hesitate to ensure that someone else is accused of his own sin. In addition to this śruti, Bhāskara quotes the following half verse as a smrti testimony: 
There is also a smrti, "the sin that belongs to one who was cursed binds the person who put the curse." (BSBhBh 186,2-3: smrtiś ca. śapyamānasya yat pāpam śapamānam niyacchatitit.)

This corresponds to the last half of the following verse incorporated into the Mahäbhärata:

The religious merit made by the person who put a curse goes to another who was cursed, whereas the sin that belongs to the person who was cursed follows another who put the curse. (MBh 14, Appendix, No. 4, 2535: śapatā yat ķtam punyam śapyamānam tu gacchati; 2536: śapyamānasya yat pāpam śapantam anugacchati /)

In the text of the MBh, the half verse has "anugacchati" (follows) instead of "niyacchati" (binds) and thereby more clearly expresses the transfer of one's sin to someone else. Bhāskara concludes his commentary on BS 3.3.28 by quoting Mn 6.79 as another smrti that corroborates the transfer of merits and sins. Despite the grave difference in the morality between the dog-eat-dog world depicted in the RV and the self-restraint exalted in the MBh, Bhāskara quotes these half verses in order to confirm the transfer of the karmic results.

In spite of criticizing Medhātithi for adapting the meaning of Mn 6.79, Kullūka, like Medhātithi, construes Mn 6.74 to say that jūāna causes liberation and 6.75 to say that karman supports it. ${ }^{16)}$ Whereas the jñannakarmasamuccayavāda is widely accepted by those who wrote a commentary on the $\mathrm{Mn}$, they differ in their views of how the consequence of good and bad deeds should be considered.

1) $\mathrm{MnV}$ 42,37 \& 43,2 ad Mn 6.74: jñānakarmasamuccayam upadeksyaty . . jñ̄ānakarmasamuccayastutir; 43,10 \& 12 ad v.75: jñānakarmasamuccaye ... vijñ̄ānakarmasamuccayah; 44,25-26 \& 35 ad v.82ab: jñānakarmasamuccayastutir . . samuccaye; MnBh 522,8 ad Mn 6.85: jñānakarmanoh samuccayān mokșa iti; 527,6 ad v.83: karmajñānasamuccayam; 527,24 ad v.85: ātmajñ̄anakarmanoh samuccaye; 531,3-4 ad v.91: jñānakarmasamuccayapaksaś cānena punarvacanena drdhīkrtah.

2 ) Cf. ŚB 10.2.6.13: . . yajñéna yajñéna haivá tám evamvid āpnoti.

3 ) Cf. Mimāmsāsūtra 4.3.5; H. Kurata, "SAMYOGAPŖTHAKTVANȲ̄YA," Journal of Indian and Buddhist Studies 28.2 (1980) : 970-975.

4 ) Cf. Brhadāranyakopanișad (K) 1.5.17: (M) 1.5.25-26; J. F. Sprockhoff, "Die Alten im alten Indien: Ein Versuch nach brahmanischen Quellen," Saeculum 30 (1979) : 374-433, esp. 386-387.

5 ) For the implication that adds the debt to men as the fourth debt, as given by ŚB 1.7.2.1-6, see Sprockhoff, op. cit., 389; Ch. Malamoud, "La théologie de la dette dans le brâhmanisme," Puruṣārtha 4 (1980): 39-62. TS 6.3.10.5 has been quoted by an opponent who asserts that there is no time to endeavor to attain emancipation (apavarga) in Nyāyabhāsya 4.1.59.

6 ) Indologica Taurinensia 14 (1987-88): 391-432.

7 ) Mn 6.79: priyeșu sveșu sukrtam apriyeșu ca duṣkrtam / vişjya dhyānayogena brahmābhyeti 
sanātanam //

8 ) prìtiparitāpakrtaś cittasaṃkṣobho harșaśokādilakṣaṇo 'nenopāyena parihartavyah. yat kiñcit priyam karoti tan mama sukğtasya viśisyate tasyedam phalam, naișa kartā mama snehabuddhyā priyam, na cāyam me śātravam śaknoti kartum duskktam pị̣̂ākaram ityevam vimrśya dhyānayogena citte bhāvayet, ato 'sya na priyakārini rāgo nāpriyakārini dveșo jāyate.

9 ) Cf. MnṬ 247,22-24: svadharmāvirodhipriyeșu kenacit krteșu na prāgjanmārjitasukrtam antarena kasyacit ghațate. . . a ātmīyam eva sukrtam kartrtvenāropya evam apriyeșv api kenacit krteșv ātmìyam eva prāgjanmārjitam duṣkrtam kāranatvena prakalpya.

10) BSŚBh 399,20-23: tathā sāâtyāyaninah paṭanti "tasya putrā dāyam upayanti suhrdah sā-

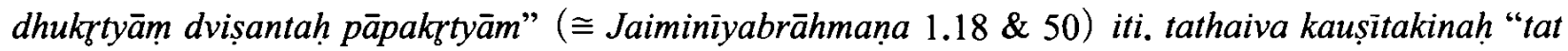
sukrtadușkrte vidhūnute tasya priyā jñātayah sukrtam upayanty apriyā dușkrtam" ( = Kaușitakyupaniṣad 1.4) iti.

11) priyeșu sveșu dharma- ${ }^{*}$ aviruddheșv ātmìyeșu svādubhaikṣalābhādiṣu ca nipatatsu kāranatvenātmiyam e[va sukrtam visrjya] dhyānayogena paramārthadarśanena viniyujya tam kāranatayā svadharmam vyudasya ca tatsampādayitāram purușam, evam apriyeșu duṣkrtam visłjya dhyānayogena param brahmābhyeti. Medhātithi's indebtedness to Bhāruci is noted by Wezler (op. cit., n. 54). * Cf. MnT 247,22: svadharmāvirodhipriyeșu in note 9.

12) In the Mìmāmsā exegetics, the term viniyoga is used in the sense of the function of a type of injunction called viniyogavidhi that assigns a ritual constituent to the means to accomplish a purpose. Cf. Mimāmsānyāyaprakāsa, ed. F. Edgerton (New Haven, 1929), §66.

13) Cf. S. Sarasvati, The Method of the Vedanta (Delhi, 1997), 534-541.

14) Owing to the letters "yavi-" instead of "parya-," the quotation that follows the introduction "tatha ca mantravarnah" in BSBhBh 186,1 does not make sense.

15) I assume that the "prakrtam" (BSBhBh 186,2) added to "akrtam" should be corrected into "parakrtam," which Dr. Takahiro Kato confirmed in the manuscripts of the BSBhBh.

16) MnM 229,29-30; cf. MnM 231,13. In his commentary on Mn 1.15, Kullūka expresses his reverence to Bhāskara (MnM 9,6: bhagavadbhāskarīyadarśane); cf. Sarasvati, op. cit., 470.

BS: Brahmasūtra; BSBhBh: Brahmasūtrabhāşya of Bhāskara, ed. V. P. Dvivedin, 1915; BSŚBh: Brahmasūtrabhāsya of Śankkara, ed. W. L. Sh. Pansikar, 1927; MBh: Mahābhārata, Poona Critical Edition; Mn: Manusmrti, ed. P. Olivelle, 2005; MnBh: Manubhäṣya of Medhātithi, ed. G. Jha, 192939, repr. 1999; MnM: Manvarthamuktāvali of Kullūka, ed. J. L. Shastri, 1983; MnṬ: Manuțīkā of Govindarāja, in Manu-Smriti with Nine Commentaries, ed. J. H. Dave, vol. 3, 1978; MnV: Manvarthavivarana of Bhāruci, ed. J. D. M. Derrett, 1975; R̊V: R̊gvedasamhitā, ed. T. Aufrecht, 2. Aufl., 1877.

(This research is supported by the 2012 Grant-in-Aid for Scientific Research (C) from the JSPS.)

〈Key words〉 jñānakarmasamuccaya, Manusmrtti, Medhātithi, Bhāruci, Bhāskara

(Professor, Tohoku University, Dr.Phil.) 